\title{
Secular Dimensions of the Aśoka Stūpa from the Changgan Monastery of the Song Dynasty
}

\author{
Yue Dai
}

check for

updates

Citation: Dai, Yue. 2021. Secular Dimensions of the Aśoka Stūpa from the Changgan Monastery of the Song Dynasty. Religions 12: 909. https:// doi.org/10.3390/rel12110909

Academic Editors: Shuishan Yu and Aibin Yan

Received: 21 July 2021

Accepted: 5 October 2021

Published: 21 October 2021

Publisher's Note: MDPI stays neutral with regard to jurisdictional claims in published maps and institutional affiliations.

Copyright: (C) 2021 by the author. Licensee MDPI, Basel, Switzerland. This article is an open access article distributed under the terms and conditions of the Creative Commons Attribution (CC BY) license (https:/ / creativecommons.org/licenses/by/ $4.0 /)$.
Department of Art History and Archaeology, Washington University in St. Louis, St. Louis, MO 63130, USA; yued@wustl.edu

\begin{abstract}
In 2008, in the course of excavating the site of the pagoda foundations of the former Nanjing Da Bao'en Monastery 南京大報恩寺, archaeologists discovered Buddhist relics enshrined in nested reliquaries along with some two hundred offering objects. The most impressive finding was a specially designed, richly decorated reliquary stūpa, known as the Seven-Jeweled Aśoka Stūpa 七寶 阿育王塔, created in the Song Dynasty (960-1279 CE). This paper begins with the history of the site where a series of famous Buddhist structures had been built since the Wu Kingdom (222-280 CE), and which has long been associated with the cult of King Aśoka and relic worship. It then goes on to examine the form and features of the reliquary stūpas prevalent in the Wuyue period (907-978). Through comparisons between the Aśoka stūpas commissioned by Wuyue King Qian Chu 錢俶 (929-988) and those by laypeople around the same time, I will demonstrate that the Seven-Jeweled Aśoka Stūpa is distinct in its secular features. It is not a Buddhist reliquary that strictly conforms to the conventions of reliquary-making in terms of scale, inscription, and functionality; besides relic worship, it also features a remarkable manifestation of laypeople's beliefs and expectations, sacred or secular. Viewed in its historical context, in which the Song emperors imposed political control over religious affairs and Buddhism became increasingly secular, the stūpa was a product of negotiation between the political authorities and local Buddhist communities in the Song Dynasty.
\end{abstract}

Keywords: Changgan Monastery; Aśoka Stūpa; Wuyue Kingdom; Nanjing; Buddhist reliquary

\section{Introduction}

During the excavation of the site of the former Nanjing Da Bao'en Monastery in 2008, archaeologists discovered the crypt of the True-Body Pagoda 真身塔 of the Changgan Monastery 長干寺built during the Song Dynasty. Through this excavation, the crypt, along with several Buddhist relics and over two hundred offering objects, was revealed to the public after an interval of nearly a thousand years. The crypt's airtight condition had helped to preserve the nested reliquaries and other precious objects therein for centuries, protecting them from natural and manmade destruction. As a result, most objects remained intact, and information on the crypt is well preserved on a stone stele titled "A Record on the Stone Casket Encasing the Relics of the True-Body Pagoda of the Jinling (Nanjing) Changgan Monastery"，金陵長幹寺真身塔藏舍利石函記 (Qi and Gong 2011, 2012; Zeng 2011; Nanjing Municipal Institute of Archaeology NMIA 2015). Among the archaeological findings, the Seven-Jeweled Aśoka Stūpa (stūpa: a dome-shaped structure that contains the relics of Buddha), also known as the Changgan stūpa (now in the collection of Nanjing Museum), has attracted the most attention and discussion.

At present, scholarship on the Changgan crypt is dominated by archaeologists, whose research concentrates on its history, structure, and extant objects. The most comprehensive publication is the excavation report by the Nanjing Municipal Institute of Archaeology (NMIA), covering the site's Buddhist history and functions as a monastery in the Ming Dynasty (1368-1644), as well as the crypt's structure and its nested reliquaries and their contents in great visual and textual detail (NMIA 2015). Several scholars have conducted 
more specific investigations into the archaic structure of the crypt and the stele inscriptions (Qi and Gong 2011, 2012; Zeng 2011). By contrast, a few scholars, such as Katherine Tsiang and Hattori Atsuko 服部敦子, have contextualized the Changgan stūpa in relation to the history of the construction of Aśoka stūpas in China (Hattori 2011; Tsiang 2017). Aside from this brief analysis, no comprehensive study of this reliquary's form, imagery, content, and inscription has so far been carried out.

In this paper, I intend to illuminate the stūpa's secular dimensions by analyzing its unique features. By "secular", I refer to features of relic worship in Chinese Buddhist history that deviate from canonical rules and meet the worldly needs of devotees, including the political purposes of rulers and the personal interests of laypeople. More specifically, "secular" refers to the distinctive aspects of the Changgan stūpa that do not conform to the strict regulations or conventions of reliquary-making in terms of scale, inscription, and functionality. Traces of public and governmental involvement can also be seen here and there, from the stūpa's exterior ornament to its interior contents. In light of these features, the Changgan stūpa is not merely a Buddhist reliquary, but a complex embodiment of religious devotion, political praise, and the wishes of individuals.

On one hand, a growing number of scholars agree that secular and sacred were not mutually exclusive in the Buddhist practices of medieval China. "Secular" does not mean a complete deviation from canonic concepts, prescriptions, and traditions, employed without restrictions. On the contrary, many Buddhist practices in medieval China integrate religious theories, traditions, and up-to-date interpretations. In particular, laypeople would incorporate their daily experiences into religious activities, drawing on Buddhist language, images, and rites to meet their own needs. For example, Buddhist believers in Dunhuang were engaged in copying scriptures and building caves to attain merit and thereby bring blessings to their ancestors, families, and themselves. ${ }^{2}$

On the other hand, the secular dimension of relic worship was not new in the Song Dynasty, nor could it be used to differentiate between Song and pre-Song Buddhism. Prior to the Song Dynasty, both Emperor Wen of the Sui Dynasty 隋文帝 (541-604) and Wu Zetian 武則天 (624-705), the female emperor of the Zhou Dynasty (690-705), had identified themselves with the cakravartin, the wheel-turning king 轉輪聖王, and built Aśoka stūpas to legitimate their rule. ${ }^{3}$ Three times during his reign, Emperor Wen sent more than one hundred relics in total to all the prefectures in the country and instructed special envoys, local officials, monks, and ordinary people to participate in the worship and enshrinement of these relics. ${ }^{4}$ Judging from the historical records in these cases, large-scale relic worship probably often involved all classes of society, and the Changgan stūpa was no exception.

The Changgan stūpa was the product of collective fundraising and donation collection, as its introductory stele indicates. In addition, the inscriptions that cover the stūpa's surface are not limited to Buddhist expressions: they include blessings for the state and political leaders and votive offerings by individuals. Both aspects will be closely examined in the following sections. This kind of inclusiveness was not common in reliquary-making prior to this. In fact, the majority of Aśoka stūpas previously made in China were commissioned by and dedicated to individuals or their families only. The most representative of this kind were the miniature stūpas favored by the ruling class and ordinary people during the Wuyue period. These stūpas, which enshrined either bodily relics of the Buddha or sutra (Dharma relics), were inscribed with the donor's name and occupation, and the date. Though the Changgan stūpa mimics the traditional form of the Wuyue stūpas in terms of its square shape, tripartite structure, Jātaka tale engravings, and other compositional elements, its unusual size $(120 \mathrm{~cm})$ and inscriptions for various subjects, as well as miscellaneous donations, make it different from its Wuyue prototype.

This study benefits from the rich collection of images and detailed textual materials provided by the archaeological report and uses them to study the site and reliquary. To explain these unusual features, I will start by introducing the history of relic worship at this site and the politico-religious tensions characteristic of its tenth-century historical context. On one hand, as many scholars have pointed out, the site of the Changgan Monastery 
had a long history of relic worship dating back to the late fourth century (Yang 2009; Qi and Gong 2011). This historical background explains the internment of Buddhist relics beneath the True-Body Pagoda of the Changgan Monastery. On the other hand, some scholars demonstrate that the Wuyue kings compared themselves to the Indian King Aśoka (303-232 BCE) by copying his feat of constructing Aśoka stūpas on a large scale, seeking to demonstrate their political legitimacy under a religious guise (Brose 2015; Shen 2019; Lee 2021). This research, however, focuses on the Wuyue kings' actions of building of stūpas, ignoring the later presence of Aśoka stūpas in the early Song Dynasty.

Unlike the Wuyue miniature stūpas, the Changgan stūpa embodies the various wishes of the regional Buddhist community, consisting of local officials, monks, and ordinary people. I articulate this idea through two comparisons. The first compares the Changgan stūpa with the Aśoka stūpas commissioned by Wuyue King Qianchu. Some scholars have conducted a visual analysis of Buddhist reliquaries in East Asia made during the tenth century (Choi 2003; Li 2009; Chen 2011). Their scrutiny of the details facilitates our comparison between the Changgan and Wuyue stūpas, highlighting three major secular features in particular.

The second comparison is between the Changgan stūpa and the Wuyue-style stūpas made by the laity around the tenth century, according to which the unconventional features of the Changgan stūpa can be explained secularly. It is in light of this social context, such as the intensified intervention of politics into religious practice, that the auspicious inscriptions blessing the emperor and his ministers can be largely understood. In addition, some scholars have shown that Chinese believers during the Tang and Song dynasties showed pragmatic and utilitarian tendencies when participating in Buddhist activities (Zheng and Lin 1996; Li 1999; Zhou 2005; Nakamura 2013). This unique characteristic is evident in the laypeople's inscriptions on and inside the Changgan stūpa, engraved on the surfaces of their offering objects or written on their wrapping textiles.

The Changgan stūpa is thus an eclectic product of secular and religious pursuits, created by the central government and the local Buddhist community. For local devotees, the concept of the Aśoka stūpa changed from a pure reliquary to a materialized embodiment of political aspirations and ultimately laymen's wishes.

\section{The History of the Site of the Changgan Monastery}

The site of the former Nanjing Da Bao'en Monastery is in the southern part of today's Nanjing. It is just outside the ancient city wall, near the south city gate-now known as Zhonghua Gate 中華門—in a place formerly known as Changgan District長干里. The bestknown Buddhist complex at this site is the Da Bao'en Monastery, with its world-famous Porcelain Pagoda 琉璃塔 built during the reign of Emperor Yongle of the Ming Dynasty 永樂(1360-1424, r. 1402-1424). This location had been occupied by a series of important Buddhist structures before the monastery was constructed. According to the Liang shu (History of the Liang Dynasty 梁書), a small vihara (an early type of small-scale Buddhist monastery) with a stūpa had been on this site since the Wu Kingdom (222-280), but was destroyed shortly after. In the Western Jin period (266-316), monks constructed a monastery with a stūpa on the same site and named it the Changgan Monastery, after the district in which it was located. The most legendary episode that ever occurred on that site was during the reign of Emperor Xiaowu of the Eastern Jin Dynasty 東晉孝武帝(r. 372-396), when the monk Liu Sahe劉薩訶 (active late fourth to early fifth century), sometimes confused with another monk, Huida 惠達 (c. 342-423) in many Buddhist narratives, arrived in Nanjing. Seeing a strange light radiating from the Changgan District, Liu unearthed two true bodily relics of the Buddha - a fingernail and a thread of hair - that had been contained in nested reliquaries beneath the stūpa of the Changgan Monastery. Liu's fruitful excavation was essentially due to his quick identification of the stūpa as one of those commissioned by Indian King Aśoka, built to enshrine the bodily relics of the Buddha (Yao, 1973, p. 791; Shi Huijiao, 1983; Jao 1990). ${ }^{5}$ After this event, the stūpa at the Changgan Monastery was 
regarded as one of the few of King Aśoka's stūpas in China in which relics of the Buddha's true body were enshrined.

From a present-day perspective, this episode of Liu's discovery of the bodily relics comes across as theatrical and thus of questionable reliability. More importantly, as a monk who had traveled throughout the central, eastern, and western regions of China and unearthed the bodily relics of the Buddha, Liu was constantly deified and idolized in a variety of narratives, ranging from officially codified history to popular folklore appearing shortly after his death. In some northwestern areas, such as Dunhuang, a cult of Liu Sahe that treated him as a Buddhist saint emerged alongside the cult of relic worship among local laypeople (Shang 2007). Despite Liu's widespread popularity, however, scholarship has long questioned the credibility of historical accounts regarding Liu and his miraculous deeds. As Wu Hung and Shang Lixin尚麗新 point out, Liu Sahe played the role of a mysterious monk with supernatural powers ever since he appeared in the very early document Gaoseng zhuan (Biographies of Eminent Monks 高僧傳). In the historical narratives, the reality and fictionality of this figure are so deeply intertwined that even contemporaries could not overcome this mystification; they simply accepted him as a legendary figure, albeit to different degrees (Wu 1996, pp. 32-37; Shang 2007). Moreover, the later the documents were composed-such as the Ji shenzhou sanbao gantong lu (Collected Records of the Miracles of the Three Jewels in Shenzhou (China) 集神州三寶 感通錄), complied during the Tang Dynasty—the more legendary elements appeared in lieu of historical facts (Shang 2007, p. 81). Nevertheless, though Liu's discovery of relics might be exaggerated or even largely manipulated, this episode indeed helped to construct the reputation of the Changgan Monastery and its significance in relic worship. Famous people who accepted this story include Emperor Wu of the Liang Dynasty and senior monks such as Huijiao (慧皎 497-554) and Daoxuan (道宣 596-667) of later generations, as can be seen in the early document Biographies of Eminent Monks and the officially codified History of Liang Dynasty.

During the Liang Dynasty (502-557), Emperor Wu 梁武帝 (464-549), a pious Buddhist, unsurprisingly paid a great deal of attention to this place and initiated a project to repair the aged structures and expand the scale of the monastery. ${ }^{6}$ He also reverently removed the relics from the stūpa several times in order to worship them personally and then had them re-encased in a grand ceremony (Yao, 1973, pp. 789-93). According to the Ji shenzhou sanbao gantong $l u$, after the Six Dynasties (222-589), the relics once enshrined in the Changgan Monastery were removed and distributed to other places at different times, leading to the gradual decline and desolation of the site (Shi Daoxuan, 1983, pp. 405-6). Nonetheless, the site has been significant to Buddhists since the Eastern Jin. It is full of historic events and symbolic meanings, which have in turn fostered Buddhist beliefs and culture over the years in southeast China.

It was not until the early Song Dynasty, after multiple petitions to the central government, that local monks managed to reconstruct the Changgan Monastery. According to "A Record on the Stone Casket Encasing the Relics of the True-Body Pagoda of the Jinling (Nanjing) Changgan Monastery", engraved on a stone stele in the crypt, the crypt was dedicated to enshrining the uṣniṣa (the round protuberance on the head of the Buddha)—one of the most precious relics of the Buddha donated by Western monk Danapala (?-1017), known as Shihu 施護in Chinese. ${ }^{7}$ With the permission of Emperor Zhenzong 宋真宗 (968-1022), local monks built a nine-story brick pagoda, the "True-Body Pagoda", a name granted by the court, completing the project in 1011. At the same time, they dug an earthen pit beneath the pagoda as a crypt. The crypt enshrined the relics in nested reliquaries, one of them the Seven-Jeweled Aśoka Stūpa (Figure 1). After the Song Dynasty, no records of the crypt or its true-body relics are found in historical documents or scholarly works. Despite how celebrated they had once been, both clergy and laity gradually forgot their existence. 


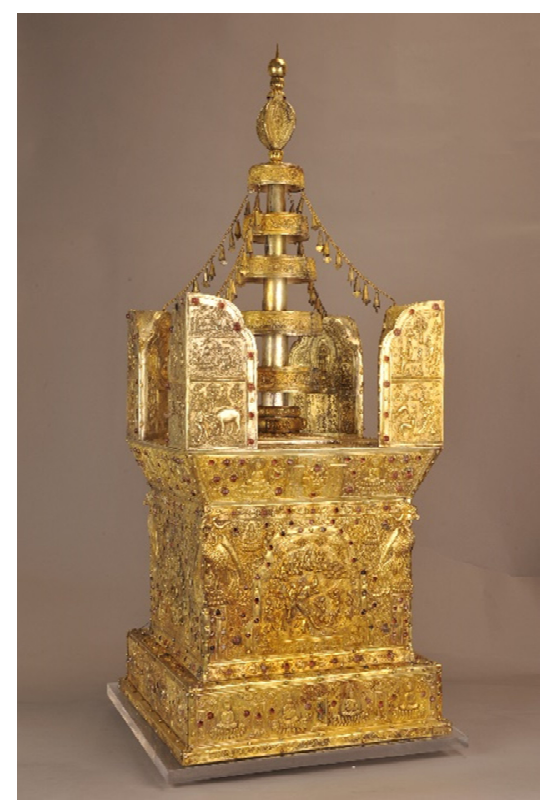

Figure 1. Anonymous. The Seven-Jeweled Aśoka Stūpa, 1011. Sandalwood and gilt silver, $117 \times$ $45 \mathrm{~cm}$. Courtesy of Zhou Baohua 周保華.

The crypt remained undisturbed, even when a majestic pagoda, commissioned by Emperor Yongle of the Ming Dynasty, was built on the site. ${ }^{8}$ With the excavation of 2008, this invaluable construction recaptured the attention of both Buddhists and scholars whose research benefited from the intact status and complete state of the buried objects.

\section{The Association between the Aśoka Cult and Relic Worship at the Site}

The history of the Changgan Monastery site shows it to be a site famed for Buddhist affairs in Southeast China, a site that had always been associated with the Aśoka cult and relic worship. The ruling class also played an important role in the Buddhist projects at the site through personal direction, financial support, and political endorsement. According to this history, the moment at which the site achieved its symbolic meaning in the history of Chinese Buddhism was in the Eastern Jin period (317-420), when Liu Sahe discovered the relics of the Buddha's fingernail and hair hidden beneath the stūpa of the Changgan Monastery. Since then, historical records of the site have usually gone hand in hand with descriptions of Buddhist activities centered on relic enshrinement and worship. For instance, after the distribution of the relics to other monasteries, ordered successively by Emperor Yang of the Sui Dynasty 隋煬帝 (569-618) and Li Deyu 李德裕 (787-850) of the Tang Dynasty, the monastery lost much of its past glory and was deserted. ${ }^{9}$ Ownership of the relics, distinguished by their scarcity and numinous power, had had far-reaching effects on local Buddhists, and evidence suggests it was the bodily relics that determined the fate of the site.

The link between the Changgan stūpa and the eighty-four thousand stūpas commissioned by King Aśoka also dates back to the mythical monk Liu Sahe's excavation of the stūpa's bodily relics (whose housing was indeed a primary function of the Aśoka stūpas). This particular role of the stūpa at the Changgan Monastery has since been accepted and reinforced from time to time. In the "Foji xu lue" (Brief Preface to the Buddhist Anthology 佛集序略) to the Guang hongming ji (Expanded Collection on the Propagation and Clarification [of Buddhism] 廣弘明集), author Shen Yue (沈約, 441-513) details nineteen of the eighty-four thousand Aśoka stūpas located in Chinese territory. He frequently uses the words "aged" and "numinous signs" to describe them. Unsurprisingly, the stūpa at the Changgan Monastery is on his list (Shen, 1983, pp. 201-2).

The very title of the "Seven-Jeweled Aśoka Stūpa" offers a clue to the function of the newly excavated stūpa and contextualizes it in the tradition of the Aśoka cult at the 
Changgan Monastery. Unlike the Aśoka stūpas commissioned by Wuyue King Qian Chu, this Aśoka stūpa was not the product of a ruler's religio-political aspiration, the assumed primary motivation behind King Aśoka's massive constructions of stūpas ${ }^{10}$ (which led rulers of later ages to legitimize and defend their political authority under the guise of devotion to Buddhism). ${ }^{11}$ Instead, the Seven-Jeweled Aśoka Stūpa was a product of a public, collective Buddhist project, patronized by the local Buddhist community, which had a strong secular dimension.

\section{The Crypt of the Song Changgan Monastery}

The crypt of the Song Changgan Monastery lies on the central axis of the former Da Bao'en Monastery, beneath the foundation of its Porcelain Pagoda (Figure 2). The crypt is in the form of a round vertical earthen shaft measuring 6.74 meters deep, making it the deepest relic crypt ever found in China (Figure 3). ${ }^{12}$ The shaft features a deep pit without additional components, and so its structure is simpler than the horizontal crypts and underground palaces common at Tang Dynasty sites such as the Famen Monastery. Qi Haining 祁海甯 and Gong Juping 壟巨平 argue that this form was commonly adopted for crypts in the early Buddhist history of China, such as that of the Yongning Monastery 永寧 寺 in the Western Wei period (386-534). Gradually, a more developed form—the horizontal brick chamber-replaced the previous plain form and dominated the spatial design of relic deposits from the Six Dynasties onwards. In Qi and Gong's opinion, the Changgan crypt's preference for the classical form suggests a revitalization of the ancient crypt style of the Six Dynasties period (Qi and Gong 2012, pp. 76-81). In other words, the form was selected out of respect for the tradition of the Aśoka cult and relic worship at the site.

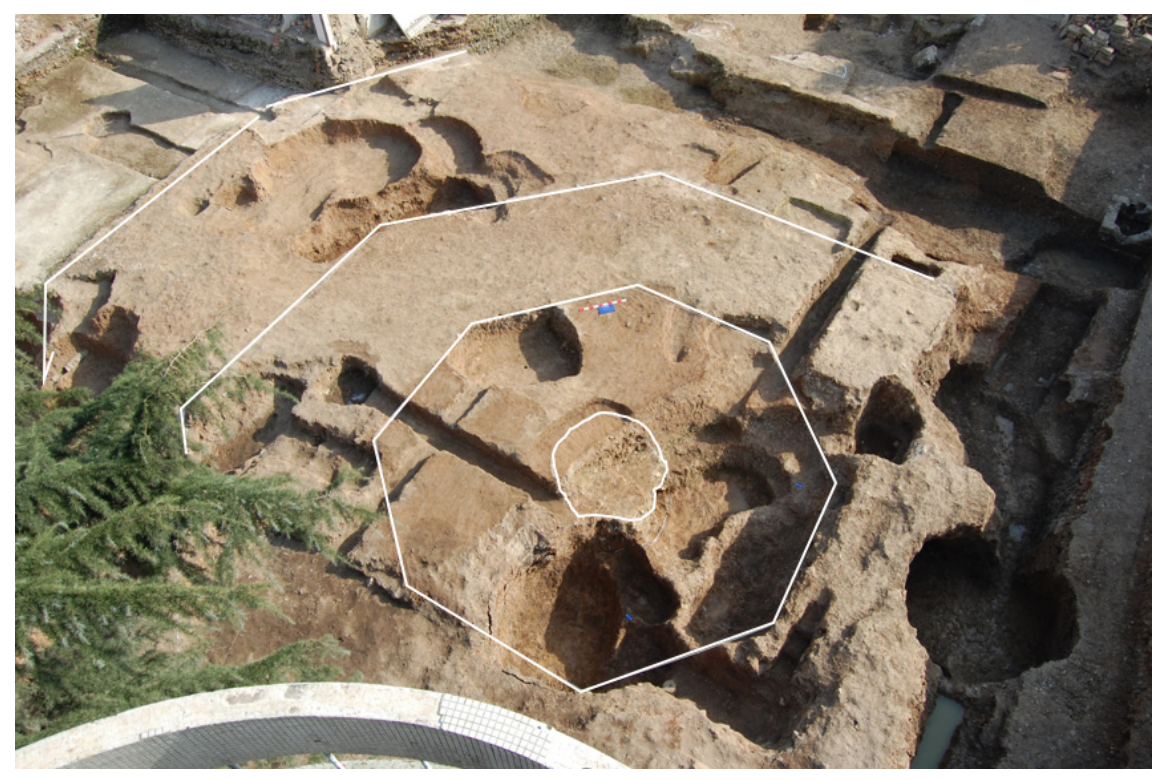

Figure 2. Bird's-eye view of the foundation of the Porcelain Pagoda before excavation. From outer to inner parts: foundation slot, outer earth rim, sandwich stone rammed layer, inner earth rim, and crypt. Photo: courtesy of Zhou Baohua. Lines added by the author. 


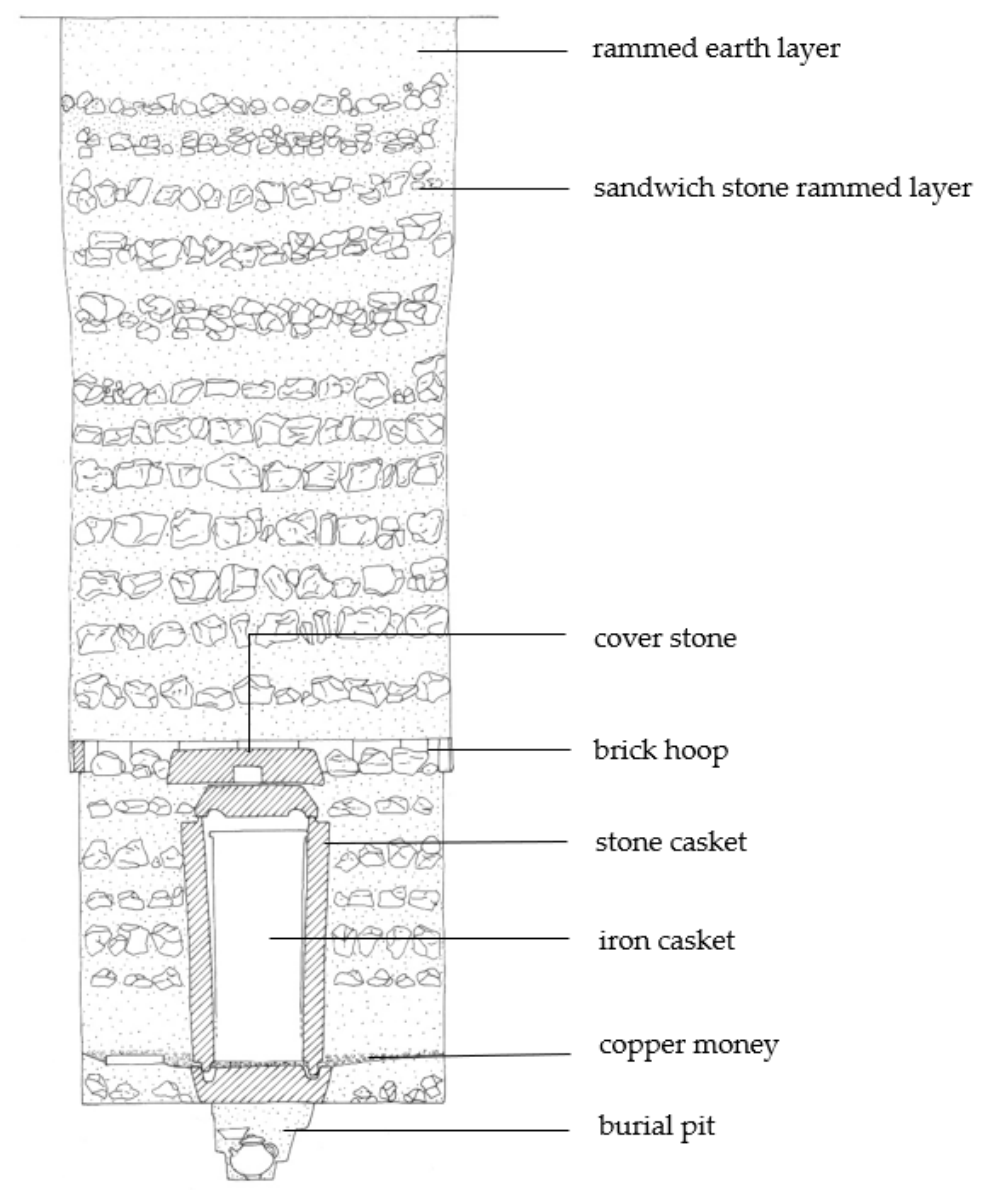

Figure 3. Profile of the crypt structure. Photo: courtesy of Zhou Baohua. Texts added by the author.

At the bottom of the crypt sits a large stone casket, 1.83 meters high, consisting of five stone slabs and a square stone base. The slab facing the northern wall is engraved with a lengthy inscription, "A Record on the Stone Casket Encasing Relics of the True-Body Pagoda of the Jinling Changgan Monastery", which functions as a merit-recording stone stele. Inside the stone casket and only slightly smaller is an iron casket in the form of a sealed cube. The most important object inside this is the Seven-Jeweled Aśoka Stūpa, measuring 117 centimeters high and 45 centimeters wide. The stūpa has a sandalwood frame; its surface is entirely covered by sheets of gilt silver, richly decorated with a variety of jewels. The stūpa is hollow and contains the uṣnisa of the Buddha, numinous-response relics 感應舍利, and the relics of holy monks, as well as some two hundred offering objects. The principal object of worship-the usnịisa —was put here with other relics in nested reliquaries, made of gold and silver and shaped like coffins. In short, the Seven-Jeweled Aśoka Stūpa is a masterpiece of Song Dynasty reliquary because of its impressive shape, precious material, elaborate ornaments, delicate craftsmanship, and abundant contents.

Since the crypt safely kept its relics until modern times, most of its items remained untouched and in good condition. Hence, the inscription on the stone stele has become a useful textual reference for examining the crypt and its buried objects and restoring them to their proper historical context. The inscription reads, in part:

...... 大事既周，提河示寂，碎黃金相為設利羅，育王鑄塔以緘藏耶。舍手光 而分佈, 總有八萬四千所, 而我中夏得一十九焉。金陵長幹寺塔, 即第二所也 ... 舊基空列於蓁無, 峞級孰興於佛事。每觀藏錄, 空積感傷。

聖宋之有天下, 封禪禮周, 汾陰祀畢, 乃有講律演化大師可政, 塔就蒲津, 願興 墜典。言告中貴, 以事聞天, 尋奉綸言, 賜崇寺、塔。同將仕郎、守滑州助教 王文, 共為導首。率彼衆緣, 於先現光之地, 選彼名匠, 造建磚塔, 高二百尺, 八角九層, 又造寺宇。 $\square \square$ 進呈感應舍利十顆, 並佛頂真骨洎諸聖舍利, 内用金 
棺, 周以銀槨, 並七寶造成阿育王塔, $\square$ 以鐵 $\square \square$ 函安置。即以大中祥符四年太 歲辛亥六月癸卯朔十八日庚申, 備禮式設閝郭大齋, 於臮際, 庶 $\square$ 名數, 永鎮坤 維。

-...

塔主演化大師可政。助緣管勾賜紫善來, 小師普倫。導首將仕郎、守滑州助教王 文, 妻史氏十四娘, 男凝、熙、規、拯 ... 僧正賜紫守邀宣慧大師齊吉, 賜紫文 仲，僧仁相，紹之。舍舍利施護、守正、重航 ...... ${ }^{13}$

... When his business (teaching the laws) was done, the Buddha entered nirvāna. His golden body was broken to make Śarīras (relics), and King Aśoka constructed stūpas to encase them. The stūpas were broadly distributed and in the total number of eighty-four thousand, there are nineteen of them in our countryZhongxia [China]. The stūpa at Changgan Monastery of Jinling is the second [Aśoka stūpa of China] ... The old foundation of the stūpa [pagoda?] was seated alone in the wild, and the grand scale indicated that thriving Buddhist affairs had once taken place. Whenever I read its collections, I could do nothing but lament. Since the establishment of the sacred Song Dynasty, the Feng-Shan ceremony has been completed, and the Fen-Yin sacrifice has been finished. Then, the lawpreaching Yanhua master Ke Zheng noted the pagoda's tendency to decline and hoped for its revival for practicing rituals. He turned to dignitaries and let the heaven (emperor) know of his proposal. Consequently, Kezheng received the emperor's decree and grant to revive the monastery and pagoda. With Wang Wen, a Jiang Shilang or assistant teacher in the Hua prefecture, Kezhang shared the role of head director. He led the laypeople and selected celebrated craftsmen to participate in the construction of the brick pagoda at the site where light had radiated throughout history. The pagoda is octagon-shaped and nine-storied, and is two hundred chi in height. Then, they continued to build structures in the monastery. $\square \square$ presented ten numinous-response relics, as well as the uṣnịșa of the Buddha and relics of holy monks. The relics are placed in nested reliquaries, which are golden, silver coffins, the Aśoka Stūpa made out of seven jewels, and the iron casket, in an outward order. On June 18, 1011, rituals were prepared and a large Zhai ceremony for the whole city was held. Next to the water, the interment is in hope for eternity.

....

The Yanhua master Kezheng in charge of the pagoda; Administrator of Buddhist affairs Shanlai; Monk Pulun; Head director Jiang Shilang; Assistant teacher of Hua Prefecture Wang Wen; his wife Shi Shisiniang; his sons Ning, Xi, Gui, Zheng ... Monks: Qiji, Wenzhong, Renxiang, Shaozhi ... Relic-donators: Shihu, Shouzheng, Chonghang ... (NMIA 2015, p. 22)

According to this inscription, the crypt was made as part of the True-Body Pagoda of the Song Changgan Monastery and dedicated to enshrining the relics presented by Shihu and others. The entire project was long and complicated. The monk Kezheng first sought recommendations from influential officials, with which he submitted a proposal to the emperor at court. After obtaining the emperor's permission, construction began under the supervision of multiple local officials responsible for religio-cultural affairs. In fact, there were more people who participated in this project than whose names are engraved on the stele; more traces can be found of many dedicatory and votive inscriptions on other objects. In the brief excavation report, the authors provide excerpts from inscriptions on the buried objects. They consist of over twenty engraved inscriptions on the surface of the Aśoka stūpa, the dedicatory inscriptions on the bottom of the gold and silver coffins, the ink inscription on the textiles, and the engraved inscriptions on the bricks. The inscriptions on the stūpa are especially distinguished by their quantity and rich content, as they intensively and evenly cover the surface, from the sides and top of the body to the foot of the chattra (a triple umbrella form on the top of the structure) and the inward-facing sides of the 
acroteria. Based on this textual evidence, we can infer additional categories of participants who did not appear in the stele inscription, such as monks from other monasteries (e.g., Siqi from the Chongsheng Monastery 崇聖寺); laypeople grouped by family ties (e.g., Chen Zhihe's 陳知厚 entire family); and individual laity (e.g., Xu Shouzhong 徐守忠 and Liu Yiniang 劉氏一娘). ${ }^{14}$ They not only offered financial support for the project, but also generously donated valuable personal belongings. For instance, a bronze mirror tied onto the chattra of the stūpa was donated by the Buddhist disciple Yinwen 印文, according to the ink inscriptions on its surface. Therefore, at least one hundred locals took part in this unusual project, regardless of occupation, gender, or social status.

\section{The Analysis of the Seven-Jeweled Aśoka Stūpa}

The stūpa is a single-storied, square container, primarily composed of a base, body, and summit. The base is low and square-shaped, with a row of four seated Buddhas in relief on each side. The four reliefs are placed horizontally and evenly spaced, forming an elegant frieze. Above the base is a cube-like container, which is the reliquary body. Each of the body's sides is engraved with a scene from the Jātaka tales, including Prince Mahāsattva giving his body to the hungry tigers, King Sibi saving a dove, King Candraprabha sacrificing his head to a brahmin, and King Sudhira donating his eyes. Besides the Buddhist icons and traditional Chinese patterns, dedicatory inscriptions and auspicious phrases take up the rest of the empty space on the surface. A capital in the shape of a garuda-a golden-winged bird in Buddhist mythology - is welded on each side of the body's edge. The cubic body is topped with a sloping cornice pointing upward. Each side of this cornice is decorated with two reliefs of seated Buddhas, echoing the base's design, but here the reliefs flank a lion-head pattern surrounded by auspicious phrases and votive inscriptions, illuminating the secular feature of this stūpa.

On the top of the cornice, four acroteria in the shape of banana leaves occupy the four corners, whose outward-facing sides are decorated with a total of nineteen narrative scenes chosen from the biography of Buddha. Each of the eight sides is engraved with two or three images, arranged vertically and divided by fine lines. Likewise, the acroteria's inward-facing sides are vertically composed, showing a figure image above and a brief inscription below. Unlike the outward sides, which focus on the Buddha himself, the four inward sides portray a variety of Buddhist icons, including standing and seated buddhas, bodhisattvas, and heavenly guardian kings. Each side is dedicated to a particular figure exclusively. A long pole stands in the center of the top, decorated with a lotus-shaped pedestal. The pole goes up to thread five tiers of disks topped by a flame-shaped orb. Four golden chains, hung with numerous celestial bells, bridge the central pole and the four acroteria at the corners. The base, body, and acroteria are hollow to hold as many relics as possible.

As a reliquary, the design of this Aśoka stūpa adopts the elements of the Aśoka stūpas popular in the Wuyue period. The key features that distinguish the Wuyue stūpas are a single story; a square shape; a three-part composition made of a base, body, and summit; scenes from the Jātaka tales on the body's four sides; and Buddhist icons on the corner acroteria. Although the gilt bronze and gilt iron stūpas slightly vary in the details of their formal design and decoration, the identifying features have been preserved and were also employed in the construction of the Changgan Aśoka stūpa. ${ }^{15}$ The Changgan Monastery is in today's Jiangsu Province, a territorial neighbor to Zhejiang Province, the core of the Wuyue Kingdom. The year of its construction, 1011, was within fifty years of the surrender of the Wuyue king and the annexation of his kingdom by the Song. Given this temporal and spatial affinity, the Changgan stūpa is likely a direct legacy of the Wuyue stūpas, and is considered to be an ideal form to worship the bodily relics of the Buddha (Figure 4). 


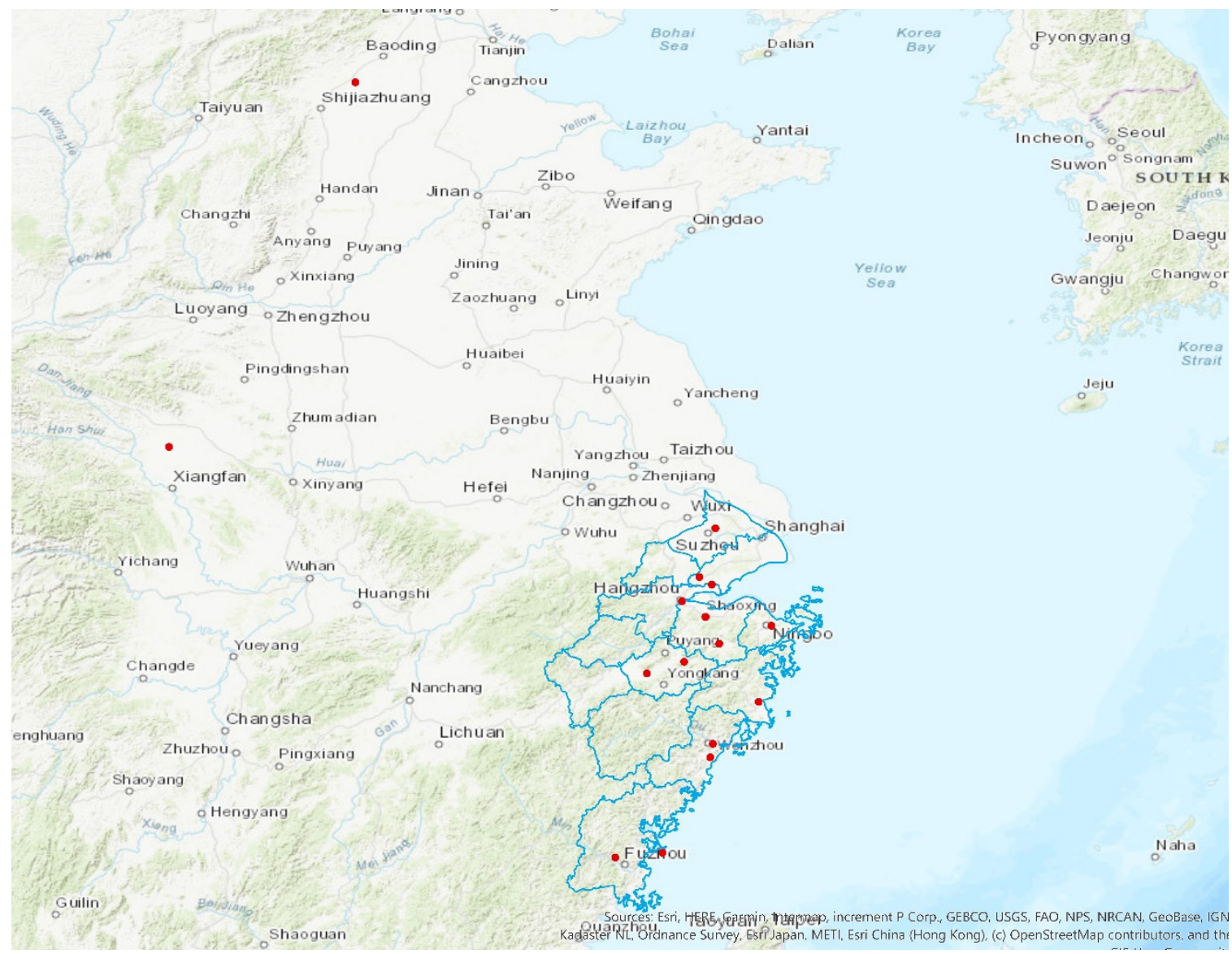

Figure 4. Distribution map of the Wuyue-style stūpas created in the mid-tenth century. (Blue boundaries: administrative prefectures of the Wuyue Kingdom. Red dots: sites of the stūpas. Feature map: (CHGIS 2016)).

The unique form of stūpa was termed as such due to its association with an Indian architectural style alien to the traditions of China. Zhang Yuhuan 張馭寰contends that the form of the Baoqieyin Stūpa (Aśoka Stūpa 寶筮印塔) originated from the stūpas of India and was later influenced by the artistic style of Gandhāra. The form diffused throughout north India, eventually arriving in China (Zhang 2000, pp. 119-20). By examining early Buddhist stūpas in India (third century-first century BCE) and innovative Gandhāran stūpas (first-fifth century CE), Alexander Soper argues that several distinguishing features, namely, the square-shaped body, garuda capitals, and even the four-sided Jātaka tales, all derive from Gandhäran artistic innovations. For instance, the Anda or hemisphere dome is the core component that distinguishes the early Indian stūpas from their descendants. However, after this architectural style spread to northern areas, the dome was gradually transformed into a squarish base and body components (Soper 1940, pp. 652-60; Chen 2006, pp. 63-64). Since the first century CE, the Gandhāran-style stūpas featuring a squarish base gradually spread eastwards to the Tarim basin and then to Central China (Whitefield 2018, pp. 88-89).

During the Han Dynasty (202 BCE-220 CE), the enhanced, bilateral connections between China and Central Asia undoubtedly accelerated the spread of Buddhism and the Gandhāran art to inner China. For instance, King Aśoka dispatched missionary campaigns traveling from India to the Tarim Basin in northwest China, during which they successfully converted lots of local people to Buddhism (Whitefield 2018, p. 83). Likewise, from the second century BCE onward, Chinese people and the government tended to move westward by means of marching, trade, pilgrimage, and so forth. ${ }^{16}$ According to Han shu (History of the Han Dynasty 漢書), the Han empire established its official connections with the kingdoms to its west after the reign of Emperor Wu漢武帝 (ca. 156-87 BCE). 
The number of these kingdoms grew from thirty-six to some fifties in decades (Ban, 1962, p. 3871), which promised safety and reliable supplies to the travelers between China and Central Asia. Consequently, international communication flourished, resulting in frequent exchanges of goods, valuable objects, and agricultural products between China and the West.

Monks were crucial to the eager travelers who traveled in both directions, accelerating the spread of Buddhism across vast areas (Nakamura 1984, pp. 11-12; Dong 2021, pp. 181-84). According to many historical records, these monks not only helped promote Buddhist scriptures and practices (Palumbo 2012), but introduced the Gandhāran style to Chinese Buddhist architecture. ${ }^{17}$ For instance, the squarish base and body of the Gandhāran stūpa contributed to the design of Chinese square-shaped stūpas and pagodas, and the four-sided Jătaka tales inspired Chinese art-making during the fifth and sixth centuries (Rhie 2010, p. 362). In Chinese pictorial art, the representation of square stūpas, single- or multi-storied, appeared as early as the Northern Wei (384-534) and Northern Qi (550-577) periods (Wang 2012, pp. 115-16). ${ }^{18}$ There is more evidence to strengthen this argument, and an excellent example is the stūpa in Mao County 鄮縣, also considered one of the nineteen Aśoka Stūpas in China.

Legend has it that the Mao County stūpa was discovered when the monk Liu Sahe found it "growing out" of the earth. Liu claimed that the unusual form of this stūpa was similar to those of the foreign kingdom of Khotan (known in Chinese as Yutian 于 闐), to be imitated by the Wuyue Aśoka stūpas. ${ }^{19}$ More importantly, the Mao County stūpa was transferred to the capital of the Wuyue Kingdom and became the property of Qian Liu 錢鏐(852-932), grandfather of Qian Chu. This episode serves as evidence for scholars who have speculated that the stūpa was a prototype of the miniature Aśoka stūpas mass produced by Qian Chu. ${ }^{20}$ In this view, patrons considered the originality and iconography of the reliquary stūpa as verifying its authenticity and superiority. In respect to the Changgan stūpa, the selection of this form was intentional, so that people would associate it with the Aśoka cult and relic worship, establishing the site's place in history.

Furthermore, the Changgan stūpa aspired to the significance of the Wuyue Aśoka stūpas, commissioned by the ruling class as well as ordinary people. In the chronicles of Fozu tongji 佛祖統紀, “Wuyue King Qian Chu was naturally disposed to have faith in Buddhism. Admiring Aśoka's building of the stūpas, he [commissioned craftsmen] to manufacture eighty-four thousand [miniature] stūpas using gilt copper and fine iron; inside [each] was deposited the Baoqieyin xinzhou jing (Sūtra on the Heart Mantra of the Precious Chest Mudrā 寶筮印心咒經). [The stūpas] were widely disseminated throughout [the kingdom]. This took in all ten years to complete" (Shi Zhiqin, 2012, p. 1018). ${ }^{21}$ So far, only around thirty-five of Qian Chu's stūpas have been found, seeming to suggest that the original "eighty-four thousand stūpas" was an exaggeration or a metaphor for devotion. Apart from the silver stūpas dedicated to the bodily relics of Buddha at the Leifeng Pagoda 雷峰塔, most of Qian Chu's stūpas were made exclusively to enshrine Dharma relics, in particular the Sütra on the Heart Mantra of the Precious Chest Mudrā. ${ }^{22}$ In the Wuyue Kingdom, the commission of the Aśoka Stūpa was not only a privilege of kings but a trend among the ordinary laity, who seemingly competed with the imperial project in terms of quantity. To date, at least twenty-three replica Aśoka stūpas built by the laity have been discovered. Most temporally and spatially overlap Qian Chu's project during the Ten Kingdoms (902-979) and the Song Dynasty, and most have been found in southeast China. Benefitting from the popularity of this particular form and its techniques, the Changgan Aśoka stūpa, constructed later, can be considered a legacy of the Wuyue stūpas, favored by all social classes. More important, the stūpa's official name- the Seven-Jeweled Aśoka Stūpa-indicates that this is the most venerated stūpa in the Lotus Sütra, and therefore surpasses the value of the Wuyue ones. ${ }^{23}$ According to the sūtra, the stūpa is adorned with seven jewels, the hardest and most imperishable materials in the world, radiating, and it miraculously appears in front of the audience. It is not surprising to see that the Changgan stūpa largely fits into its description, and demands a proper treatment of "made 
offerings ... reverently worshipping it, holding it in solemn esteem, and singing its praises" (Hurvitz 1976, p. 183).

\section{Interpretation of Distinguished Features from a Secular Perspective}

Admittedly, the Changgan stūpa was made in the tradition of Chinese reliquary stūpas, but further questions about its nature require answers. What distinguishes this stūpa from other Aśoka stūpas? What do these features imply? Based on visual characteristics and textual sources, we can conclude that the stūpa has three notable features. First, the scale of the Changgan stūpa is massive, much larger than the Aśoka stūpas of the Wuyue period. According to previous scholarship, the average height of the Aśoka stūpas in the Wuyue period was 30 centimeters, making them portable reliquaries. ${ }^{24}$ In contrast, the Changgan stūpa is 120 centimeters tall, four times the size of the Wuyue stūpas, making it less portable. Second, its surface is heavily covered with inscriptions, including both auspicious phrases and dedicatory inscriptions (Figure 5). Among the inscriptions are “Long live the emperor皇帝萬歲”, “Praise to important officials for 1000 years 重臣千秋", “Peace for the masses in this world 天下民安”, and “Timely wind and rain風調雨順”. The dedicatory inscriptions offer a detailed record of benefactors-their names, occupations, and donated objects- that is absent from the Aśoka stūpas commissioned by Wuyue King Qian Chu. Third, as a reliquary stūpa, the Aśoka stūpa is dedicated to bodily or Dharma relics exclusively, in a narrow interpretation of its function, with other offering objects placed outside of it in the hollow body of a stone casket. However, given the considerable space in the body of the Changgan stūpa reliquary, many other relics and offering objects were stuffed inside, violating the defined role of the reliquary stūpa and obfuscating its functionality.

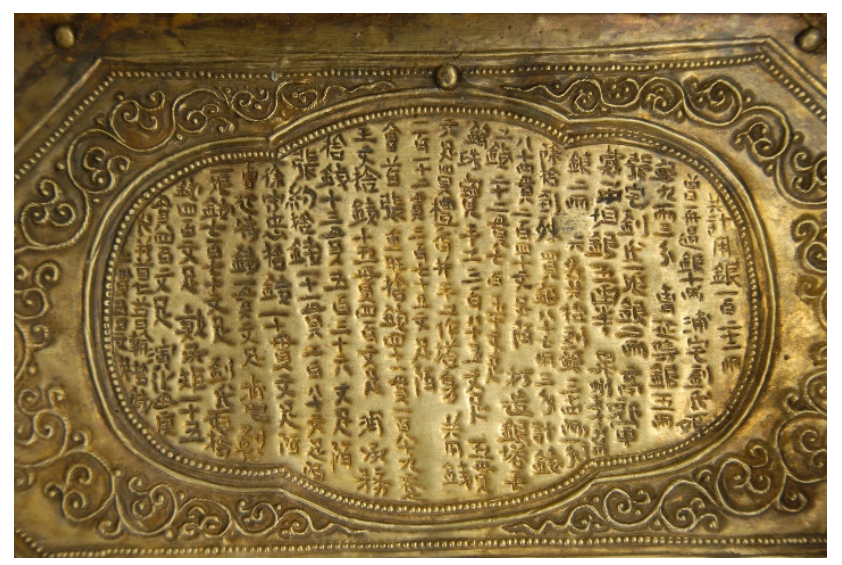

Figure 5. Anonymous. Dedicatory inscriptions on the Changgan stūpa. Courtesy of Zhou Baohua.

The Aśoka stūpas commissioned by Wuyue King Qian Chu appear to be more elegant but stylistically less sophisticated than the Changgan stūpa. With the exception of Buddhist icons and traditional decorative patterns, no ornaments can be seen on its surface. The only engraved text is a short dedicatory inscription from Qian Chu on the bottom (Figure 6): "The king of Wuyue, (Qian) Chu, has reverently made 84,000 precious stūpas as eternal offerings, recorded in 955 or $965^{\prime \prime} .{ }^{25}$ The creators' lack of interest in additional inscriptions is obvious, with no textual information on the surface of the gilt silver Aśoka stūpas at the Leifeng Pagoda; only images are visible. The purpose of creating these Aśoka stūpas, as Shi Zhiru points out, was to stress the Wuyue king's devotion to Buddhism and embody his political legitimacy by repeating King Aśoka's feat of building eighty-four thousand stūpas. ${ }^{26}$ As the only owner of merit, Qian Chu did not need to express his religio-political aspirations explicitly. Rather, he reinforced his political position by imitating King Aśoka's act of building and charging certain stūpas with symbolic meaning. 

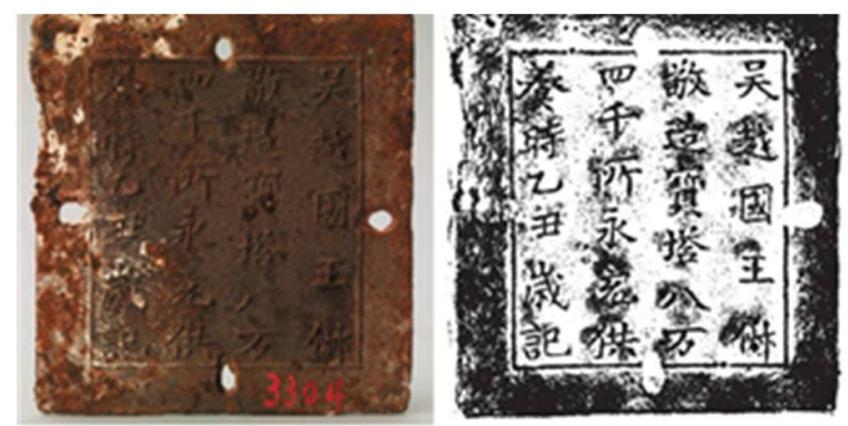

Figure 6. Qian Chu (commissioner). The bottom side of the Aśoka Stūpa, 965. Iron, Huangyan District Museum (Li 2009, p. 38).

The richness of quantity and content, highlighted by the inscriptions on the Changgan stūpa and the offering objects within, may be due to its secular dedication as a counterpoint to the ideology of the ruling class. As mentioned earlier, similar votive inscriptions were found on handwritten scriptures by laypeople of the Tang Dynasty at Dunhuang, seeking the Buddha's blessing for their ancestors, family, and themselves (Yu 2011, pp. 167-68). However, in contrast with these inscriptions-composed, displayed, and taking effect individually - the votive inscriptions of the Changgan stupa, seen in numerous places on its surface as well as on the donated objects inside, show a diversity of gender, provenance, social class, and identity, forming a heterogeneous network that embodied the collective participation of local believers. There are at least thirty inscriptions that can be categorized into two groups. The first are the dedicatory inscriptions, typical on the surface of Aśoka stūpas, recording the donor's name, occupation, and details surrounding the donation. For instance, an inscription on the bottom of the gold coffin states: "Four liang of gold, donated by Wang Wen, the head of the community for building the Pagoda of the Changgan Monastery, Jiang Shilang, assistant teacher in the Hua Prefecture, and his wife Shi Shisiniang; three liang of gold, donated by Shao [?], Chonghui master in charge of the first Aśoka stūpa".

The second group consists of votive inscriptions, represented by ink inscriptions on the textiles used to wrap the objects. These add the donor's vows to the basic information stated in the dedicatory inscriptions. For example, an inscription on a yellowish-brown silk cloth states:

高郵軍左廂招賢坊弟子荀懷義謹舍水晶杯一隻, 碧琉璃杯一隻, 白硨磲念珠一 串, 幸遇皇帝建金陵長幹寺阿育王所造釋迦佛真身舍利塔, 下收葬供養舍利。 所願劫劫生生長承佛護。時大宋大中祥符三年 $\square$ 月日日，弟子荀口記.

Xun Huai, a Buddhist disciple from Zhaoxian Lane, Junzuo Xiang of Gaoyou, reverently donated a crystal cup, a green-glass cup, and a string of prayer beads made of white shells. Fortunately, I had a chance to contribute to the construction of the True-Body Pagoda, built by King Aśoka to intern the relics for enshrinement and worship, under the emperor's commission. I wish for the eternal protection of the Buddha, in the date [?] of 1010, recorded by the disciple Xun [?]. (Figure 7; NMIA 2015, p. 41) 


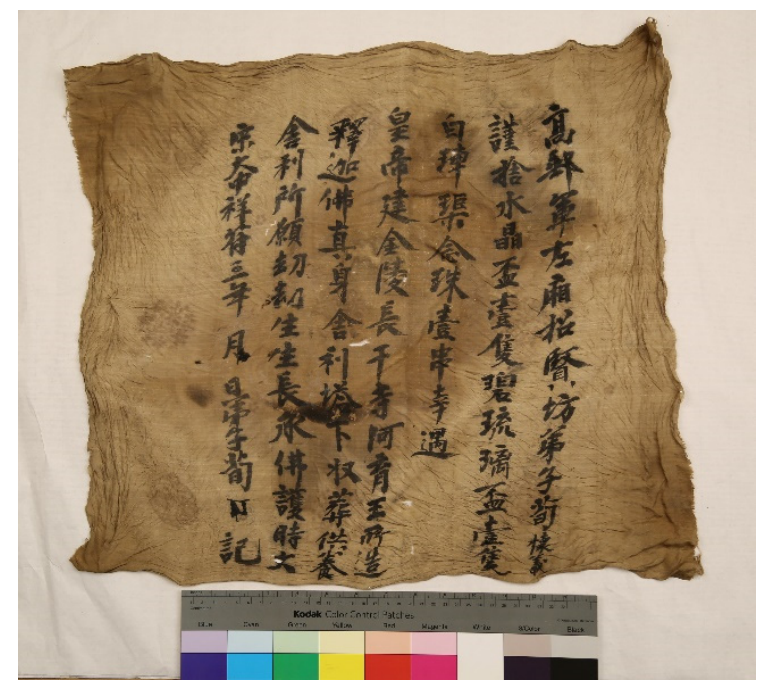

Figure 7. Xun Huai (donor). Silk wrapping, 1011, yellowish-brown, Nanjing Museum. Courtesy of Zhou Baohua.

Other inscriptions include four-character auspicious phrases, such as "Long live the emperor" and a Buddhist poem.

Apparently, the local Buddhist community was inclusive, heterogeneous, and collective, its participants drawn from a wide swath of society, from local officials to monks and ordinary believers. The community was also cohesive and collaborated on this project under the guidance of its leaders, Kezheng and Wang Wen. Since the producers of merits were the entire community, the contributions of every member of the community, including their vows, needed to be clearly documented. This was different from what Qian Chu had done with his stūpas. The contents of the votive inscriptions not only pertained to religious pursuits such as Buddha's protection and the rebirth of the deceased in Buddhist lands, but also revealed several secular hopes, such as good wishes for the emperor and the country's prosperity. These secular desires indicate the diverse expectations and feelings of the common people. Given that utilitarianism and practicality are prominent features of folk Buddhism, it is reasonable to suspect that ordinary people with limited education were not engaged with Buddhist theology. Rather, their emphasis was on Buddhist practices said to produce merit, to be rewarded either in this life or the afterlife. ${ }^{27}$ The increasing and consistent participation of ordinary believers in Buddhist affairs accelerated the processes of simplification, socialization, and secularization in folk Buddhism.

Further evidence has been found to explain the uncommon features of the Changgan stūpa by comparing it to other stūpas or Buddhist projects locally commissioned during the Wuyue and Song eras. The imitation Aśoka stūpas, commissioned by Wuyue laity, share with the Changgan stūpa the engraved inscriptions that provide patrons' names and occupations, dates, and the purposes of the commissions. For instance, two bronze Aśoka stūpas were excavated at the site of the Qiyuan Monastery 祇園寺 in Xiaoshan in 1966. A dedicatory inscription carved on the rim of the stūpa body's top states that "the disciple Xia Chenghou and his wife Lin Yiniang, with their entire family, donated all their money to create the two stūpas for true-body relics. In fear of the ample sinful and Dharma hindrance which we pray to eliminate, we hope to undertake the good and reach the pure land in the West; recorded on the 3rd of November, 958" (Figure 8; Chen 2011, p. 34). These inscriptions are similar to those on the Changgan stūpa and offering objects in terms of their locations on the object, their medium, and their contents. The more people who participated in a project, the more diverse their hopes and wishes. Moreover, with more people involved, the roles of the reliquary became more complex, as we know from the Changgan stūpa. In this sense, the reliquary stūpa per se is no longer strictly defined as a container for relic deposits, but a container of laypeople's hopes. 


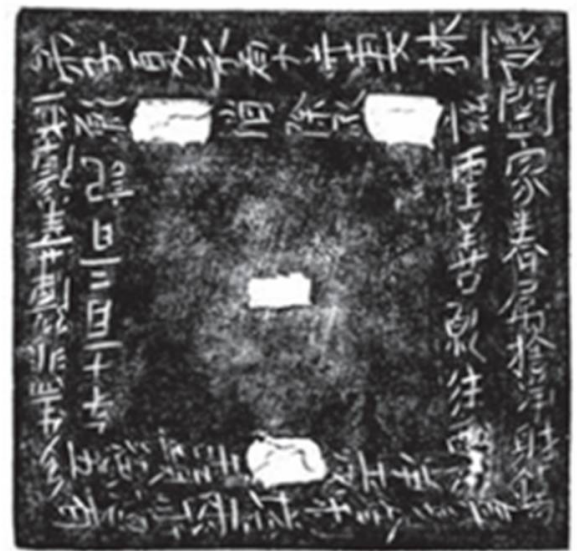

Figure 8. Xia Chenghou (commissioner). The upper side of the body of the Aśoka Stūpa, 958. Bronze, Xiaoshan District Museum (Li 2009, p. 42).

The Changgan stūpa needs to be temporally contextualized from a political and religious perspective so as to facilitate a better explanation of its uncommon features. In the early Song Dynasty, the emperors were often ambivalent about Buddhist affairs and enacted moderate policies towards them in order to maintain social stability and win the support of the people. In its first sixty or seventy years, the Song court also used Buddhism to link China and Central Asia, welcoming Western monks to China to promote Buddhism and translate sūtras. Song Zhenzong, the third emperor of the Song Dynasty, was no exception. He was committed to reconciling Buddhism with Confucian ethics in order to cultivate society. ${ }^{28}$ According to the stone stele of the crypt and historical documents, we know that the usnīsa enshrined in the crypt was a gift from the monk Danapala from Udgana in Northern India. This gift fits with Song Zhenzong's support for Western monks. However, at the same time, the Song court appeared more conservative in its approach to Buddhism, compared to many Tang emperors' devotion to Buddhism. In practice, the Song court intervened more in Buddhist activities and monastic management. For example, the Northern Song emperors inherited the policy of "Request and Grant Plaques" introduced by the Tang emperors to establish their authority in Buddhist affairs, which aimed to control the quantity and scale of monasteries. ${ }^{29}$

According to the stone stele of the crypt, the titles of Changgan Monastery and the True-Body Pagoda were granted by Song Emperor Zhenzong. Their construction and the relic worship subsequently associated with them could not have occurred without the emperor's endorsement. Under these circumstances, any Buddhist activities must have been dependent on political authority and demonstrated obedience to the ruling class. Therefore, it is understandable why the four auspicious phrases, though unrelated to Buddhism, appear prominently on the stūpa.

The first cave of the Gezitou Grotto 閣子頭石窟 was commissioned by laypeople and finished in 1112, near the end of the Northern Song Dynasty. In it, there are similar four-character auspicious phrases, including "Long live the emperor", "Praise ministers for a thousand years", "Stable state and peaceful life", and "Timely wind and rain", (Yuan 1986, pp. 12-13). These secular and political vows reflect the dependence of the local Buddhist community on imperial power, and the compromises they made in its name. They also reflect the extension of folk beliefs to the religious sphere.

Because of its scale, the construction of the crypt and the enshrinement of the uṣnissa must have involved a considerable number of participants. Their success likely lay in the organization and management of the local Buddhist community. Beginning in the Tang Dynasty, with the spread of Buddhism and the urban population growth, relic worship evolved from an elite culture dominated by royalty and the aristocracy to a collective activity accessible to all social classes. ${ }^{30}$ Important projects such as the worship of true- 
body relics demanded the collaboration of many to pool human, material, and financial resources. Since the late Tang, local Buddhist communities, called Sheyi 社邑, Yiyi邑義， or Yihui邑會, had emerged, forming a stable organization in the Northern Song Dynasty. These communities were often centered at a particular Buddhist monastery and engaged in organizing Buddhist activities, celebrating Buddhist festivals, or participating in the construction of Buddhist structures (Gao 2017, pp. 251-52; Teiser 2020, pp. 157-59). Since many communities maintained a high degree of inclusiveness and publicized their activities, membership included ordinary believers, lay Buddhists, and local officials. The inscriptions on the stele and other buried objects specify who held the positions of "head director" and "head of the community." Under their guidance and management, ordinary believers could contribute to and accelerate these projects.

\section{Conclusions}

Wuyue kings manifested their religio-political aspirations when the role of Aśoka stūpas transitioned from bodily reliquary stūpas to containers for Dharma relics. The SevenJeweled Aśoka Stūpa of the Changgan Monastery can be seen as a synthesized product of the heritage of the Aśoka cult and relic worship at this site, the adoption of Wuyue miniature reliquary stūpas, the participation of ordinary believers, and the negotiation between political and religious power. The Changgan stūpa changed its function from a pure reliquary to a materialized embodiment of laypeople's beliefs and expectations. On one hand, the Aśoka stūpa was no longer a depository for a particular type of relic, but a symbol of relic worship with conceptual significance. The three types of relics-the uṣnịsa, numinous-response relics, and the relics of holy monks-were simultaneously stowed in the same nested reliquaries. On the other hand, the abundant offering objects, with numerous votive inscriptions, reveal the pragmatic and utilitarian demands of relic worship, displaying the degree of Buddhist secularism in the lower Yangtze River region during the Song Dynasty. With respect to secular features of Song Buddhism, the presentday scholar Ge Zhaoguang 葛兆光 contends that Chinese religions are distinguished by their tendency for pragmatism, which tends to be a psychological comfort, a strategy, or anything besides a pure belief system. Instead of being passive to religious doctrines, the Chinese believers showed remarkable agency by adapting religion to their own interests (Ge 1996, p. 42). Likewise, the Aśoka stūpa of the Changgan Monastery is a reformed reliquary in terms of conception, function, and purpose, and a good representation of secular Buddhism from the Song Dynasty. Through scrutiny of this invaluable reliquary, present-day people can get a glimpse of the artistic innovations and the indigenous practice of relic worship in Nanjing during the Northern Song Dynasty.

Funding: This research received no external funding.

Institutional Review Board Statement: Not applicable.

Informed Consent Statement: Not applicable.

Data Availability Statement: Not applicable.

Conflicts of Interest: The author declares no conflict of interest.

\section{Notes}

1 In recent years, a growing number of scholars have opposed the strict separation of the secular and the sacred in medieval Buddhist practice. Through a close reading of extant materials, they contend that many of the Buddhist practices of laypeople showed a mixture of sacred and secular features, incorporating a variety of factors such as religious imagination, socio-political contexts, and personal interests. See (Copp 2011; Sun 2019; Teiser 2020, pp. 171-72). Sun Yinggang 孫英剛 points out that the boundary between religious and secular texts, monastic and worldly identities, and beliefs and ideologies in medieval China was constantly changing (Sun 2020).

2 From his study of the family caves at Dunhuang built during the Tang Dynasty, Winston Kyan contends that the boundaries between secular and sacred spaces in these caves are ambiguous. Many murals show a mixture of Buddhist, Confucian, and 
Daoist icons, or flaunt the luxurious furnishings and material opulence belonging to this family. In addition, the images depicting ancestor worship directly reflect Confucian ideas, revealing the commissoner's secular considerations. See (Kyan 2010).

3 Onishi Makiko 大西磨希子and Jinhua Chen have demonstrated the ideological meanings behind Emperor Wen's distribution of relics across the country. In particular, the latter argues that this action was not only a device to legitimize the emperor's rule, but also an aid in breaking down racial and cultural barriers to his reunification of the country. See (Chen 2002, p. 42; Onishi 2020).

4 The Edict on Building Stūpas Across the Sui State states that each monastic group should be cautious and diligent and travel taking good care of the relics. Before the groups enter their respective prefectures, ordinary people should have their homes cleaned of all filth. Regardless of belief and gender, people came from all over the city to welcome the returning monks. The prefectural supervisor, governor, and other officials stood along the street and led the team to their destination. The four sections of the people were all arrayed in a solemn manner. See (Yang, 1983, p. 213; Fairbank 1957, pp. 101-2). By analyzing Emperor Wen's call to the whole state to participate in the ritual of relic worship and enshrinment, Zheng Yi 鄭argues that the emperor and nobles were primary beneficaries, despite the involvement of the alleged "all living beings". Therefore, this case is different from the making of the Changgan stūpa, which allowed laypeople to be merit owners. See (Zheng 2016).

5 Wu Hung has summarized the scholarship on Liu Sahe and demonstrated how he became a religious icon in relation to relic worship in medieval China. See (Wu 1996, pp. 32-36). Although Liu's miraculous deed-the discovery of the Buddha's bodily relics beneath the Changgan stūp—is recorded in the History of Liang Dynasty, Chen Zhiyuan 陳志遠points out that the mystification of Liu first developed in central China, and then slowly expanded to the southeast of the country. See (Chen 2020).

6 Emperor $\mathrm{Wu}$ identified himself as the golden wheel-turning king/cakravartin, following Aśoka's identification as the iron wheel-turning king. See (Endo 2021).

7 Zeng Liping曾立平 has researched the provenance of the bodily relics of the Changgan Monastery and briefly introduces the northern Indian monk Shihu and his donation of the uṣnīṣa. See (Zeng 2011, p. 70).

8 The Ming gazette Jinling fancha zhi (A Record of Jinling Buddhist Monasteries 金陵梵志) contains only a record of the history of the site where the Changgan Monastery had been located, but no details on the construction of the True-body Pagoda or the interment of the relics. These had been forgotten by later generations, and thus the crypt remained closed and intact from the Song Dynasty onward. See (Ge, 2007, pp. 459-93).

9 The record of Emperor Yang of Sui's distribution of the relics is also included in Fayuan zhulin (The Pearl Forest in the Dharma Park法苑珠林), see (Shi Daoshi, 2003). The record of Li Deyu's distribution is on the stone stele of the crypt of the Ganlu Monastery 甘露寺. A brief description of his actions can be found in (Mao 2009, pp. 212-20).

10 John Strong has carried out a meticulous study of King Aśoka's act of building eighty-four thousand stūpas and its political implications. The king sought to identify himself as a cakravartin, the universal king in India culture. Strong also points out that rulers in other countries, such as Japan, emulated this act as a metaphor for their own political legitimacy. See (Strong 1983, pp. 109-25).

11 In a survey of the relic cult practised by rulers in medieval China, Liu Shufen discovered that they sought to legitimize their political authority via this cult. For example, Emperor Wen of the Sui Dynasty ordered a massive project of stūpa building across the country and asked that relics be interred simultaneously on the same day (Liu 2008, pp. 318-22). Shi Zhiru has studied the building of Aśoka stūpas and the acquisition of the Mao County Aśoka stūpa by the Wuyue kings, and concludes that as one of ten kings in China at that time, Qian Chu was anxious to justify and defend his political position by imitating King Aśoka's contribution to Buddhism and expanding his own religio-political influence. See (Shi 2013, pp. 83-109).

12 For detailed information on the crypt of the Song Changgan Monastery, see (NMIA 2015, pp. 4-54).

13 For the entire inscription on the stele, see (NMIA 2015, pp. 14-15).

14 To read the full contents of some of the inscriptions, see (NMIA 2015, pp. 19-48).

15 Most of the gilt bronze stūpas were built in $955 \mathrm{CE}$, while the gilt iron ones were built in 965 . The gap between the production of the two groups of stūpas led to nuanced differences (Chen 2011, pp. 29-30). Lee Seunghye also compared the features of the two groups, and found that major differences lay in the structure and Buddhist iconography. See (Lee 2013, pp. 57-60).

16 As Susan Whitefield points out, Buddhists and merchants established a "symbiotic" relationship as the former spread their religion to foreign areas along the trade routes (Whitefield 2018, p. 85). In another book, Whitefield demonstrates that the development of these trade routes, or the so-called Silk Road, largely resulted from the westward expasion of China since the second century BCE and the rise of the Kushan empire in the first century CE (Whitefield 2015, p. 2). Other scholars emphasize the importance of officials among this group of travelers. Dong Lili argues that soldiers and government officials constituted a large part of the travelers in the early Han Dynasty. One piece of evidence is that the Han emperors commanded military campaigns to combat Huns and therefore protect the western border for years (Dong 2021, pp. 25-26). Besides that, Emperor Wu, in particular, sent his envoy Zhang Qian 張騫 (ca.164-114 BCE) to the western kingdoms twice in order to form military allies. After Zhang's final return in 126 BCE, the Han empire began expanding its control to the west (Hansen 2012, p. 14).

17 By examing the historical records, Xinru Liu stressed that in the first century CE, monks and their merchant patrons brought Buddhist texts and monasteries to China via the Silk Road. See (Liu 2010, pp. 58-59). 
However, the four acroteria that often embellished Chinese Aśoka stūpas had no counterparts in ancient India or Gandhāra. Soper suggests, despite a lack of convincing evidence, that this unusual form might have developed from the harmikâ, a square-shaped fence standing on the top of early Indian stūpas. In this regard, Wang Chung-cheng's 王鐘承 speculation may be more persuasive. Wang argues, through a comparision of acroteria and the architectural elements depicted in Han dynasty rubbings, that this distinctive form originated from the Chinese roof decoration on its wings. After being transformed and refined multiple times, the roof decoration lost its original function and became an eye-catching ornament on Chinese Aśoka stūpas. Therefore, acroteria can be seen as a symbol of the sinicization of Indian architecture. See (Wang 2012, pp. 116-17).

19 For a description of the Mao County stūpa, see (Shi Daoxuan, 1983, p. 404). Shi Zhiru translated the Chinese passage into English. See (Shi 2013, p. 92). Like the episode of Liu's identification of the Changgan stūpa with the King Aśoka stūpas, his identification of the Mao County stūpa is also rife with myth and hyperbole. Scholars such as Wang Chung-cheng question the story's reliability. However, its semi-fictionality does not change the fact that many noble people in medieval China worshiped this reliquary with great devotion. See (Wang 2012, pp. 123-26).

Zhejiang Museum (2008, p. 9). By comparing the images and compositions on several Chinese Aśoka stūpas, Hattori Atsuko suggests that since the Tang Dynasty, the designs of Chinese Aśoka stūpas had more or less been based on the Mao County stūpa, despite nuanced pictorial details. See (Hattori 2011, p. 125). Shi Zhiru translated the Chinese passage into English. See (Shi 2013, p. 56).

Li Yuxin has collected and arranged information on excavated Aśoka stūpas, especially those built in the Wuyue period, and painstakingly lists many details about most of the excavated or extant Aśoka stūpas. See (Li 2009, pp. 36-41).

John Thompson articulates the construction and veneration of the many-jeweled stūpa described in the Lotus Sūtra. As its official name indicates, the Changgan stūpa can be categorized into this group, ranking the highest among all sorts of stūpas. See (Thompson 2008, pp. 126-27).

The average size was calculated by the present author, based on data from excavated Wuyue Aśoka stūpas, and the date taken from Li Yuxin's article. See (Li 2009, pp. 36-41). For the complete contents of Qian Chu's dedicatory inscription, see (Zhejiang Museum 2008, p. 8).

Shi Zhiru has demonstrated the political motivations behind the Wuyue kings' devotion to Buddhism by studying the Aśoka cult favored by the Qian family, their imitated act of the mass production of stūpas, and their ownership of aged Aśoka stūpas with symbolic meanings. See (Shi 2013, pp. 83-109).

Through an analysis of the production of Buddhist images by local people in southern China during the Tang and Song dynasties, Si Kaiguo summarizes the key characteristics of folk Buddhism as practicality and utility. The social status of the believers defined the quality of these two characteristics, meaning the eclectic and realistic selection of images emphasizes Buddhist beliefs, such as transmigration. See (Si 2013, pp. 210-13). For more on the Song emperors 'attitudes and policies toward Buddhism, see (Pan 2000, pp. 476-79).

Lee's dissertation argues that political and religious contexts must be considered in order to understand the contents of the dedicatory wishes. Most of the dedicatory wishes were written to protect the living or to ask for a better afterlife for deceased relatives. However, due to the unstable political and social environment of the Southern Song Dynasty, many votive inscriptions began with a blessing for the emperor. See (Lee 2013, p. 213).

30 Beginning with the introduction of Buddhism in the Eastern Han, relic veneration shifted from an event favored by the upper social classes to a publicly accessible affair. The watershed moment for this change was during the Tang and Song Dynasties. For more on this process, see (Liu 2008, pp. 322-27).

\section{References}

\section{Primary Sources}

Ban, Gu 班固. 1962. Han shu 漢書. Beijing: Zhonghua Book Company.

Ge, Yinliang 葛寅亮. 2007. Jinling fancha zhi 金陵梵志. Tianjin: Tianjin renmin chubanshe.

Shen, Yue 沈約. 1983. Foji xu lue佛集序略. In Taishō shinshū dai zōkyō 大正新脩大藏經, vol. 52. Edited by Takakusu Junjirō 高楠順次郎, Watanabe Kaikyoku 渡海旭, et al. Taipei: Xinwenfeng Press, pp. 201-2.

Shi, Daoshi 釋道世. 2003. Fayuan zhulin 法苑珠林, vol. 3. Beijing: Zhonghua Book Company.

Shi, Daoxuan 釋道宣. 1983. Ji shenzhou sanbao gantong lu集神州三寶感通錄. In Taishō shinshū dai zōkyō, vol. 52. Edited by Takakusu Junjirō, Watanabe Kaikyoku et al. Taipei: Xinwenfeng Press, pp. 404-35.

Shi, Huijiao 釋慧皎. 1983. Gaoseng zhuan 高僧傳. In Taishō shinshū dai zōkyō, vol. 50. Edited by Takakusu Junjirō, Watanabe Kaikyoku et al. Taipei: Xinwenfeng Press, pp. 201-2.

Shi, Zhiqin 釋志磐. 2012. Fozu tongji jiaozhu佛祖統紀校注, vol. 44. Shanghai: Shanghai guiji chubanshe.

Yang, Jian 楊堅. 1983. Sui guoli shelita zhao 隋國立舍利塔詔. In Taishō shinshū dai zōkyō. vol. 52. Edited by Takakusu Junjirō, Watanabe Kaikyoku et al. Taipei: Xinwenfeng Press, pp. 97-363.

Yao, Silian 姚思廉. 1973. Liang shu梁書. Beijing: Zhonghua Book Company. 


\section{Secondary Sources}

Brose, Benjamin. 2015. Patrons and Patriarchs Regional Rulers and Chan Monks during the Five Dynasties and Ten Kingdoms. Honolulu: University of Hawaii Press.

Chen, Jinhua. 2002. Sarira and Scepter. Empress Wu's Political Use of Buddhist Relics. Journal of International Association of Buddhist Studies 25: 33-150.

Chen, Lu 陳露. 2006. Cong bamianti fota kan Jiantuoluo yishu zhi dongchuan 從八面體佛塔看胖陀羅㙯術之東傳. Xiyu yanjiu 西域研 究 4: 63-72.

Chen, Ping 陳平. 2011. Bawan siqian ayuwang ta (shang)—Wuyue ayuwang ta shangjie八萬四千阿育王塔(上)一吳越阿育王塔賞介. Rongbao Zhai 榮寶齋 1: 22-31.

Chen, Zhiyuan 陳志遠. 2020. Handi sheli chongbai de xingqi-Nanchao fojiao guojiahua zhi yiduan漢地舍利崇拜的興起一南朝佛 教國家化之一端. Paper presented at the “Keywords of the Liu-Song Dynasty劉宋關鍵詞國際學術研討會”; Taipei: Institute of Literature and Philosophy, Academia Sinica, December 14.

CHGIS. 2016. Version: 6. (c) Fairbank Center for Chinese Studies of Harvard University and the Center for Historical Geographical Studies at Fudan University.

Choi, Eung-Chon. 2003. Early Korean and Japanese Reliquaries in Relation to Pagoda Architecture. In Transmitting the Forms of Divinity: Early Buddhist Art from Korea and Japan. Edited by Naomi Noble Richard. New York: Japan Society, pp. 178-89.

Copp, Paul. 2011. Manuscript Culture as Ritual Culture in Late Medieval Dunhuang: Buddhist Talisman Seals and their Manuals. Cahiers d'Extrême-Asie 20: 193-226. [CrossRef]

Dong, Lili 董莉莉. 2021. Sichou Zhi Lu yu Han Wangchao de Xingsheng 絲綢之路與漢王朝的興盛. Ph.D. dissertation, Shandong University, Jinan, China.

Endo, Yusuke 遠藤祐介. 2021. Ryō butei ni oke ru risō teki kōtei zō: Bosatsu kin rinō to shi te no kōtei 梁武帝理想的皇帝像:菩薩金輪王 皇帝. Journal of Institute of Buddhist Culture, Musashino University 37: 1-32.

Fairbank, John King. 1957. Chinese Thought and Institutions. Chicago: University of Chicago Press.

Gao, Jixi 高繼習. 2017. Zhongguo Gudai Sheli Digong Xingzhi Yanjiu 中國古代舍利地宮型制研究. Ph.D. dissertation, Shandong University, Jinan, China.

Ge, Zhaoguang 葛兆光. 1996. Nayige Fojiao, Nayige Daojiao: Tan Zhongguo Zongjiao yu Wenhua Yanjiu Zhongde Yige Wenti 哪一個 佛教, 哪一個道教-談中國宗教與文化研究中的一個問題. Dongfang 東方 3: 39-42.

Hansen, Valerie. 2012. The Silk Road: A New History. New York: Oxford University Press.

Hattori, Atsuko 服部敦子. 2011. Aikuō tō no zōryū ni kansuru ichi kōsatsu—bukkyō zuzō no kentō o chūshin ni -阿育王塔造立一 考察—教像討中心一. In Wuyue shenglan guoji xueshu yantaohui lunwen ji 吳越勝覽國際學術研討會論文集. Beijing: Zhongguo shudian, pp. 107-19.

Hurvitz, Leon. 1976. Scripture of the Lotus Blossom of the Fine Dharma. New York: Columbia University Press.

Jao, Tsung-I. 1990. Liu Sahe shiji yu ruixiang tu 劉薩訶事跡與瑞應圖. In Dunhuang Shiku Yanjiu Guoji Taolunhui Wenji 敦煌石窟研究國 際討論會文集. Shenyang: Liaoning Meishu Chubanshe, pp. 336-49.

Kyan, Winston. 2010. Family Space: Buddhist Materiality and Ancestral Fashioning in Mogao Cave 231. The Art Bulletin 92: 61-82. [CrossRef]

Lee, Seunghye. 2013. Framing and Framed: Relics, Reliquaries, and Relic Shrines in Chinese and Korean Buddhist Art from the Tenth to the Fourteenth Centuries. Ph.D. dissertation, University of Chicago, Chicago, IL, USA.

Lee, Seunghye. 2021. What Was in the 'Precious Casket Seal'? Material Culture of the Karaṇamudrā Dhāraṇī throughout Medieval Maritime Asia. Religions 12: 1-19.

Li, Zhengyu 李正宇. 1999. Tangsong Dunhuang Shisu Fojiao de Jingdian Jiqi Gongyong 唐宋敦煌世俗佛教的經典及其功用. Journal of Lanzhou Vocational Technical College 1: 9-36.

Li, Yuxin 黎毓馨. 2009. Ayuwang Ta Shiwu de Faxian yu Chubu Zhengli 阿育王塔實物的發現與初步整理. Cultural Relics of the East 31: 36-41.

Liu, Shufen 劉淑芬. 2008. Zhonggu de Fojiao yu Shehui 中古的佛教與社會. Shanghai: Shanghai Guji Chubanshe.

Liu, Xinru. 2010. The Silk Road in World History. Oxford and New York: Oxford University Press.

Mao, Ying 毛穎. 2009. Zhenjiang Ganlu Si Tangdai Sheli Yimai Zhidu ji Shelizi Yanjiu 鎮江甘露寺唐代舍利痤埋制度及舍利子研究. Tangshi luncong 唐史論叢 1: 212-20.

Nakamura, Hajime 中村元. 1984. Zhongguo Fojiao Fazhanshi 中國佛教發展史. Translated by Wan-Chu Yu 余萬居. Taipei: Heavenly Lotus Publishing Co., Ltd., vol. 1.

Nakamura, Hajime 中村元. 2013. 東洋人思惟方法 (Ways of Thinking of Eastern Peoples: India, China, Tibet, Japan). Translated by Xu Fuguan 徐復觀. Taipei: Student Book Press.

Nanjing Municipal Institute of Archaeology (NMIA). 2015. Nanjing Da Bao'en Si Yizhi Taji yu Digong Fajue Jianbao 南京大報恩寺遺址 塔基與地宮發掘簡報. Cultural Relics 5: 4-54.

Onishi, Makiko 大西磨希子. 2020. Sokuten bukō to aiku ō-Gihō nenkan no shari hanpu to『daiun he sho』o megu^ te 則天武后阿育 王一儀鳳年間舍利頒布『大雲經疏』." Dunhuang Nianbao 14: 1-17.

Palumbo, Antonello. 2012. Models of Buddhist Kinship in Medieval China. In Zhonggu Shidai de Liyi Zongjiao yu Zhidu 中古時代的禮 儀、宗教與制度. Edited by Yu Xin. Shanghai: Shanghai Guji Chubanshe, pp. 287-338.

Pan, Guiming 潘桂明. 2000. Zhonggu jushi fojiao shi中國居士佛教史. Beijing: China Social Science Press. 
Qi, Haining 祁海寧, and Juping Gong 龔巨平. 2011. 'Jinling Changgansi Zhenshenta Cang Sheli Shihan Ji' Kaoshi ji Xiangguan Wenti ‘金陵長干寺真身塔藏舍利石函記'考釋及相關問題. Southeast Culture 1: 68-75.

Qi, Haining 祁海寧, and Juping Gong 龔巨平. 2012. Beisong Changgansi Gnashengta Digong Xingzhi Chengyin Chutan 北宋長干寺感 聖塔地宮形製成因初探. Southeast Culture 1: 76-82.

Rhie, Marylin M. 2010. Early Buddhist Art of China and Central Asia. Leiden: Brill, vol. 3.

Shang, Lixin 尚麗新. 2007. ‘Dunhuang gaoseng' Liu Sahe de shishi yu chuanshuo ‘敦煌高僧'劉薩訶的史實與傳説. Journal of Southwest Minzu University (Humanities and Social Science) 4: 76-82.

Shen, Hsueh-Man. 2019. Authentic Replicas: Buddhist Art in Medieval China. Honolulu: University of Hawai'i Press.

Shi, Zhiru. 2013. From Bodily Relic to Dharma Relic Stūpa: Chinese Materialization of the Aśoka Legend in the Wuyue Period. In India in the Chinese Imagination: Myth, Religion, and Thought. Edited by John Kieschnick and Meir Shahar. Philadelphia: University of Pennsylvania Press, pp. 83-109.

Si, Kaiguo 司開國. 2013. Tangsong Shiqi Nanfang Minjian Fojiao Zaoxiang Yishu唐宋時期南方民間佛教造像㙯術. Beijing: China Social Science Press.

Soper, Alexander C. 1940. Japanese Evidence for the History of the Architecture and Iconography of Chinese Buddhism. Monumenta Serica 4: 638-79. [CrossRef]

Strong, John. 1983. The Legend of King Aśoka: A Study and Translation of the Aśokavadana. Princeton: Princeton University Press.

Sun, Yinggang 孫英剛. 2019. Liangge Chang'an: Tangdai siyuan de zongjiao xinyang yu richang yinshi 兩個長安 : 唐代寺院的宗教信 仰與日常飲食. Literature, History, and Philosophy文史哲 4: 38-59.

Sun, Yinggang 孫英剛. 2020. Foguang xia de chaoting: Zhonggu zhengzhishi de zongjiao mian 佛光下的朝廷 : 中古政治史的宗教面. Journal of East China Normal University (Humanities and Social Science) 1: 47-57.

Teiser, Stephen F. 2020. Terms of Friendship: Bylaws for Associations of Buddhist Laywomen in Medieval China. In At the Shores of the Sky: Asian Studies for Albert Hoffstädt. Edited by Paul W. Kroll and Jonathan A. Silk. Leiden: Brill, pp. 154-72.

Thompson, John M. 2008. The Tower of Power's Finest Hour: Stupa Construction and Veneration in the Lotus Sutra. Southeast Review of Asian Studies 30: 119-36.

Tsiang, Katherine R. 2017. The 'King Aśoka' Type of Stūpa and Its Multivalent Meanings 阿育王式塔所具有的多種意義. Translated by Wang Pingxian. Dunhuang Research 2: 22-34.

Wang, Chung-cheng 王鍾承. 2012. Wuyue guowang Qian Hongchu zao ayuwang ta吳越國王錢弘俶造阿育王塔. National Palace Museum Research Quarterly 29: 109-78.

Whitefield, Susan. 2015. Life Along the Silk Road: Second Edition. Oakland: University of California Press.

Whitefield, Susan. 2018. Silk, Slaves, and Stupas: Material Culture of the Silk Road. Oakland: University of California Press.

$\mathrm{Wu}$, Hung. 1996. Rethinking Liu Sahe: The Creation of a Buddhist Saint and the Invention of a 'Miraculous Image'. Orientations 27: 32-43.

Yang, Yongquan 楊永泉. 2009. Nanjing zai zhongguo fojiao wenhua zhong de diwei 南京在中國佛教文化中的地位. Nanjing Journal of Social Sciences 南京社會科學 2: 7-14.

Yu, Xin 余新. 2011. Personal Fate and the Planets: A Documentary and Iconographical Study of Astrological Divination at Dunhuang, Focusing on the 'Dhāran̄ī Talisman for Offerings to Ketu and Mercury, Planetary Deity of the North'. Cahiers d'Extrême-Asie 20: 163-90. [CrossRef]

Yuan, Anzhi 員安志. 1986. Shanxi fuxian shiku si kancha baogao 陝西富縣石窟寺勘察報告. Relics and Museology 6: 1-18.

Zeng, Liping 曾立平. 2011. Beisong jinling changgan si zhenshen ta digong fajue yu fo dingzhengu sheli chongguang 北宋金陵長干寺 真身塔地宮發掘與佛頂真骨舍利重光. Identification and Appreciation to Cultural Relics 4: 68-75.

Zhang, Yuhuan 張馭寰. 2000. Zhongguo ta中國塔. Taiyuan: Shanxi People's Publishing House.

Zhejiang Museum, ed. 2008. Dongtu Foguang: Zhejiang Sheng Bowuguan Diancang Daxi 東土佛光:浙江省博物館典藏大系. Hangzhou: Zhejiang Ancient Books Publishing House.

Zheng, Yi 鄭. 2016. Daocheng sheli: Chongdu Renshou nianjian Suiwendi feng'an fo sheli shijian 道成舍利：重讀仁壽年間隋文帝奉安 佛舍利事件. Art Research 藝術研究 3: 63-70.

Zheng, Liyong 鄭立勇, and Songguang Lin 林松光. 1996. Shilun zhongguo minzhong de zhuti zongjiao yishi texing 試論中國民衆的主 體宗教意識特性. Studies in World Religions 3: 11-16, 155-56.

Zhou, Xueqin 周雪芹. 2005. Cong Dunhuang Fayuanwen Kan Tangsong Shiqi Minzhong de Fojiao Xinyang敦煌愿文看唐宋期民的佛 教信仰. Master's thesis, Minzu University of China, Beijing, China. 